\title{
Nanotechnology, Biology, Ethics and Society: Overcoming the Multidisciplinary Teaching Challenges
}

Linda Vanasupa, Matthew Ritter, Barbara Schader, Katherine Chen, Richard Savage, Peter Schwartz, and Lynne Slivovsky California Polytechnic State University, San Luis Obispo, 93407

\begin{abstract}
One of the inherent challenges of teaching any emerging technology like nanotechnology, is the fact that its core competencies flux in the new disciplines' early stages. Nanotechnology presents an additional challenge in that its underpinnings cross multiple traditional disciplinary boundaries. We have designed a course that aims to address some of these challenges through a handful of structural features: team-based learning; a "reverse of the learning pyramid" approach; team-teaching; embedded information literacy techniques; and application-centered content. Our course is organized around four applications that are in their developmental stages: gold nanoshells for cancer treatment; molecular manufacturing; tissue engineering of a vital organ; and a microfluidic glucose sensor. These applications provide natural contexts for learning biology at the cellular level, the molecular level, the organ level and the biological systems level, respectively. They also provide natural contexts to introduce ideas of scientific uncertainty in emerging fields. In this paper, we will present the design features of our sophomore-level course Nanotechnology, biology, ethics and society and some preliminary results.
\end{abstract}

\section{INTRODUCTION}

Nanotechnology presents a particular challenge for educators because its draws from several disciplines. As an emerging technology, many of the newest developments in this field exist in primary literature, such as journal articles (rather than secondary, such as textbooks). Additionally its potential applications, such as biomedical devices or detection systems for biological warfare, are also intimately tied to societal issues. Combined, these aspects of nanotechnology create a rich learning opportunity for educators to explore ethical and societal implications of nanoscale science and technology while building students skills to critically think. This paper describes the structure of our sophomore-level course, Nanotechnology, Biology, Ethics and Society, and results showing changes in students' attitudes and motivations.

\section{COURSE STRUCTURE}

Our course, designed by a multidisciplinary team of faculty, strikes a balance between depth and breadth by exploring four applications of nanoscale science and engineering (NSEE). It was geared toward sophomores in science and engineering majors; each had a year of chemistry, physics and calculus. The four nanotechnology examples that we chose span four levels of complexity in biology: the cell level, the organ level, the biological systems level and the ecological level. Each application is intimately tied to NSEE and biotechnology and serves as a complete learning module. Figure 1 depicts the teaching framework for each application: we presented each module by starting with the NSEE application; we proceeded to its scientific underpinnings; we completed the application with exploring its ethical and societal implications. The module begins with the application as a means of "hooking" students" interest and providing a motivation for them to learn the material. 
FRAMEWORK FOR PRESENTING EACH FOCAL POINT

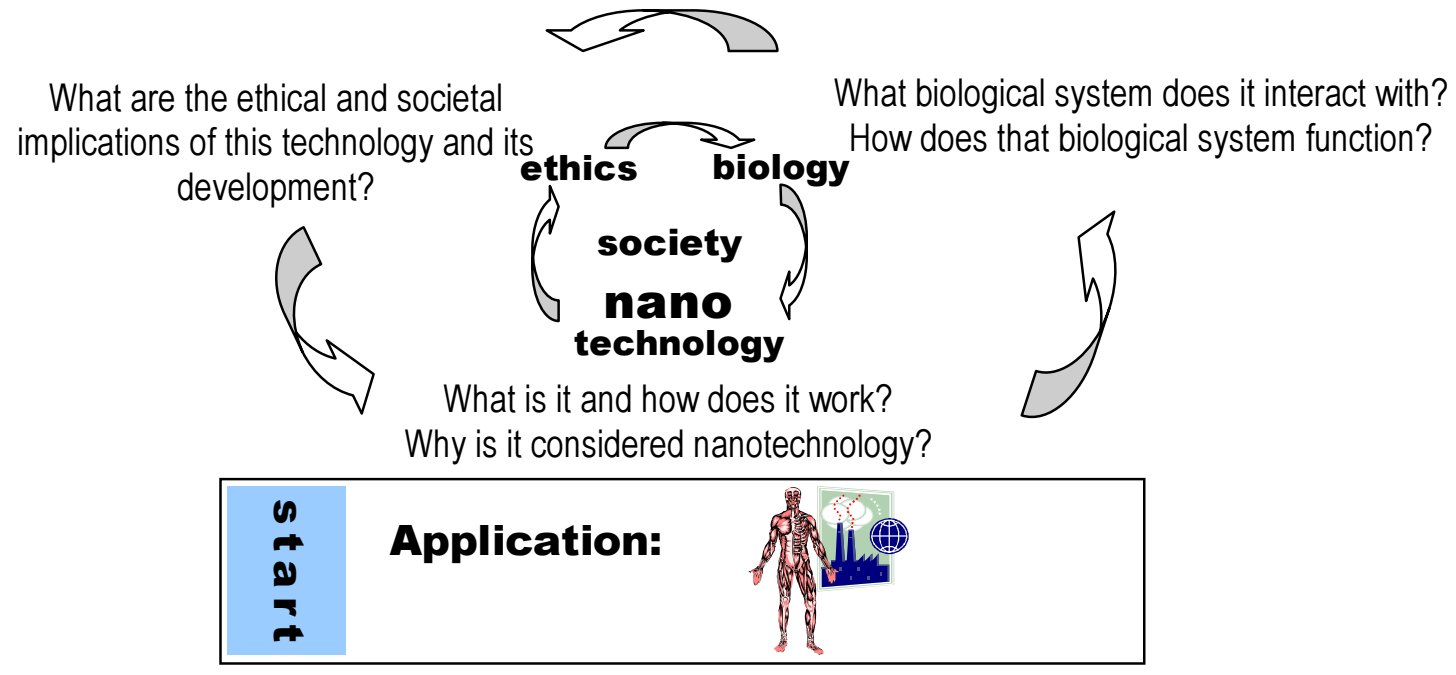

Figure 1. Module Structure. Each module begins with the application.

The format of the course drew heavily from the well-researched team-based learning strategy ${ }^{1}$ in which the instructor creates formal groups of five to seven students on the first day of class and students negotiate the weighting for individual and team performance. During class, students engage in carefully-designed applications of the reading materials in their teams. Class time spent on each module (three to four 2-hour sessions) is structured to ensure individual accountability and promote the development of higher-order cognitive skills (i.e., the ability to apply the material that is learned).

The general flow of each 2-hour class session began with individual accountability through individual quizzes. This is followed by an opportunity for the team to take the same quiz. They are then given the answer and an opportunity to write written rebuttals that explain why their answer is valid. This is followed by instructor input and/or feedback, a group activity, and simultaneous presentation of team results.

Primary information sources (versus secondary, such as textbooks) constitute the assigned reading. Researchers involved in NSEE provide mini-lectures (20 minutes) in select class periods. After the four modules (roughly $80 \%$ of the course), student teams are assigned a debate issue that bridges NSEE, ethics and society. They are given one week for their team to research the issue. In lieu of a final exam, the course culminates in structured team debates in which they are assigned the pro or con perspective and given 15 minutes to prepare their arguments. The debate judges, who are given clear instructions on the scoring criteria, include faculty outside the course and fellow students.

Table I outlines the reading and activities for five modules. As indicated, we began with the idea of molecular manufacturing. This module topic, because it has been speculated that molecular manufacturing will replace $20^{\text {th }}$ century manufacturing techniques ${ }^{2}$, provided a context to discuss manufacturing and its impact on the environment (i.e., it encompasses the ecological level). It allowed us to introduce the fundamental nanotechnology concepts of molecular recognition and self assembly. Dr. Pete Schwartz gave an introductory lecture on his work in self-assembly of nanospheres ${ }^{3}$ and the role of scanning probe techniques ${ }^{4}$. It also served as a platform to 
introduce a means of evaluating scientific authority of authors and publications. Our librarian (Barbara Schader) guided the students on how to utilize electronic search tools and guided them through an exercise on systematically evaluating the authority of an information source. The first module set the stage for addressing the ethical issues. The modules that followed incorporated engineering computations.

In lieu of a final exam, each team was given a debate topic and two weeks to complete research on the topic. BS instructed them on the format of a formal debate. The teams did not know what side of the debate they were to take until the time of their debate in which they were given 15 minutes to prepare their strategy. This activity was a culmination of their research skills, critical thinking abilities, their knowledge of NSEE, and their ability to engage in systems thinking.

At first glance, some of the activities look far beyond the capability of the sophomore students (e.g., activity in the tissue engineering of an organ: "Based on the hepatocyte cell dimensions, microblood vessel dimensions and artificial liver design constraints listed in the reading, design an implantable tissue scaffolding for an artificial liver using planar microfabrication technology.") These activities are designed to bring together the course material in a challenging application that requires a team effort. They utilize the well-documented effective learning technique called cooperative learning or group learning, which has been shown to result in a greater depth of understanding (for example, see Springer, Stanne and Donovan ${ }^{5}$ or Colbeck, Campbell and Bjorklund ${ }^{6}$ ). These activities engage students in the process of applying their knowledge, promoting the development of higher levels of cognitive functioning. More often than not, courses emphasize the lower cognitive levels, such as knowledge and comprehension. Higher cognitive levels, such as application, synthesis, analysis and evaluation ${ }^{7}$ are required by the interdisciplinary and complexity of NSEE. The activities give them opportunities to experience mastery of the material, a quality that has been shown to be the single-most influential source of students' belief that can accomplish their goals ${ }^{8}$. Unsurprisingly, this belief has been strongly-linked to persistence in a difficult endeavor ${ }^{9}$, such as majoring in science and engineering fields of study.

In the exercise on tissue engineering, students have read a document on tissue engineering scaffoldings, and have had mini-lectures ( 20 minutes) on microfabrication and the function of the liver. They are given enough information to come up with a design concept which includes artificial vascular channel dimensions and total device geometry. Clearly, there are several other issues that would come into play in a full device design (e.g., fluid dynamics). We don't expect them to address all issues. The exercise of designing the scaffolding helps them think through and apply the concepts. It provides an opportunity for them to apply their background knowledge as well as the knowledge that they learn during the course. In the "real world," this exercise would be among the first steps to develop ball-park figures for the design of a tissue engineered liver scaffolding.

\section{RESULTS TO DATE}

At the time of this writing, we are about three quarters through our pilot offering of this course with 36 students (lead by LV, MR and BS). The majority of the class time was spent addressing a particular question in their teams. For example, at the end of Module 1, we had the students read the National Society of Professional Engineer's statement on ethics. They were then charged with the task of identifying the endpoint for engineers' responsibility for the safety and welfare of the public in a product life cycle. The groups were given this task after reading a case study on events surrounding an incident at a poly vinyl chloride manufacturing plant. 
Table I. Listing of module reading assignments, lecture topics and activities for modules 1-5. The lecturer for the mini-lecture is indicated by the initials in ( ).

\begin{tabular}{|c|c|c|}
\hline \multirow{9}{*}{ 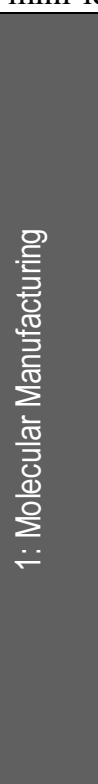 } & Reading & $\begin{array}{l}\text { "Voodoo Science, The Seven Warning Signs of Bogus Science," (Robert L. Park) } \\
\text { "Self Replicating Systems and Molecular Manufacturing." (Ralph Merkle) }{ }^{11}\end{array}$ \\
\hline & lectures & $\begin{array}{l}\text { Ecology fundamentals (MR); Manufacturing practices (LV); Evaluating information and its sources critically } \\
\text { (BS) }\end{array}$ \\
\hline & activity & $\begin{array}{l}\text { Critically evaluate Merkle reading against the criteria in the Park article and the mini-lecture material. } \\
\text { Identify the statement in the Merkle reading that most undermines the scientific credibility of the document. }\end{array}$ \\
\hline & Reading & $\begin{array}{l}\text { "Little Big Science," Sci. American: Sept. } 2001 \text { (Gary Stix) }{ }^{12} \\
\text { "Machine-Phase Nanotechnology," Sci. American:Sept. } 2001 \text { (Eric Drexler)13 } \\
\text { "Of Chemistry, Love and Nanobots," Sci. American:Sept. } 2001 \text { (Richard Smalley) }{ }^{14}\end{array}$ \\
\hline & lectures & $\begin{array}{l}\text { Molecular recognition and self-assembly in the context of DNA replication (MR); self-assembly of } \\
\text { nanospheres and the role of scanning probe techniques (PS) }\end{array}$ \\
\hline & activity & $\begin{array}{l}\text { Based on the U.S. Federal government spending (budget data) and Health } 2005 \text { (Center for Disease } \\
\text { Control), recommend the amount of an increase or decrease in spending for nanotechnology research. } \\
\text { Provide three bullet points that justify your recommendation. }\end{array}$ \\
\hline & Reading & "The Pirates of Illiopolis", Orion (Sandra Steingraber) ${ }^{15}$ \\
\hline & lectures & Poly vinyl chloride chemistry and manufacture (LV) \\
\hline & activity & $\begin{array}{l}\text { Evaluate the data on PVC precursors in the EPA's Toxic Release Inventory. Using this data and the } \\
\text { National Society of Professional Engineer's statement on ethics, identify the endpoint in a product life cycle } \\
\text { for engineers' responsibility for the safety and welfare of the public. }\end{array}$ \\
\hline \multirow{6}{*}{ 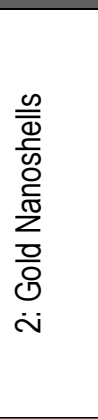 } & Reading & $\begin{array}{l}\text { "Science, Sustainability, and the Human Prospect," Science (Peter H. Raven)16 } \\
\text { "Nanoshells: Gifts in a gold wrapper," Nature Materials } 2 \text { (Mark L. Brongersma) })^{17}\end{array}$ \\
\hline & lectures & Gold nanoshells for cancer (LV); Cell life and death and the influence of heat (MR) \\
\hline & activity & $\begin{array}{l}\text { Based on the data of cell protein activity versus temperature and mass analysis of human cells, compute } \\
\text { the approximate thermal energy range needed per volume to kill cancerous tissue. }\end{array}$ \\
\hline & Reading & $\begin{array}{l}\text { "Immunotargeted Nanoshells," Science (Loo, Lowery, Halas) })^{18} \\
\text { "Nanotechnology takes aim at cancer," Science (Robert F. Service) })^{19}\end{array}$ \\
\hline & lectures & Synthesis, process of gold-coated nanoshells (KC); cancer pathology (MR) \\
\hline & activity & $\begin{array}{l}\text { Based on the absorption efficiency data, compute the approximate energy of the near infra-red radiation } \\
\text { that a patient would need to be exposed to in order to kill a cancer cell with gold-coated nanoshells. }\end{array}$ \\
\hline \multirow{3}{*}{ 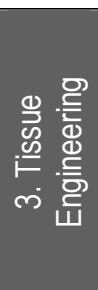 } & Reading & $\begin{array}{l}\text { Hepatic Tissue Engineering (Chan, Berthiaume, Nath, Tilles, Toner, and Yarmush) })^{20} \\
\text { Scaffolds for Tissue Fabrication (Peter X. Ma) })^{21}\end{array}$ \\
\hline & lectures & $\begin{array}{l}\text { Microfabrication techniques for tissue scaffolding (RS); liver function (MR); Artificial Implantable Liver } \\
\text { devices (LV) }\end{array}$ \\
\hline & activity & $\begin{array}{l}\text { Based on the hepatocyte cell dimensions, microblood vessel dimensions and artificial liver design } \\
\text { constraints listed in the reading, design an implantable tissue scaffolding for an artificial liver using planar } \\
\text { microfabrication technology. }\end{array}$ \\
\hline \multirow{3}{*}{ 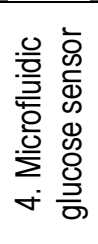 } & Reading & "A new monolithic microbiosensor for whole blood analysis," Sensors and Actuators (J-H. Kim et al. $)^{22}$ \\
\hline & lectures & $\begin{array}{l}\text { Glucose, insulin regulation in the digestive system (Lars Tomanek); Amperometric sensors (LS); Type II } \\
\text { diabetes pathology (MR) }\end{array}$ \\
\hline & activity & $\begin{array}{l}\text { Based on Center for Disease Control data on trends in early onset of Type II diabetes and federal budget } \\
\text { data, identify a source of displaced funding and develop a strategy for increasing the public health and } \\
\text { welfare around Type II diabetes and its effects. }\end{array}$ \\
\hline \multirow{3}{*}{ 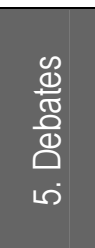 } & Topic 1 & $\begin{array}{l}\text { RESOLVED: Health care products containing nanocrystalline particles should be allowed on the market } \\
\text { before toxicology studies of the nanocrystalline particles. }\end{array}$ \\
\hline & Topic 2 & $\begin{array}{l}\text { RESOLVED: Public funds should be expended for nanotechnology/biotechnology development even } \\
\text { though access to treatment by lower-income sectors is less than high-income sectors }\end{array}$ \\
\hline & Topic 3 & $\begin{array}{l}\text { RESOLVED: New technologies should be developed regardless of the potential uses these technologies } \\
\text { may have so that the United States can maintain their technological advantage. }\end{array}$ \\
\hline
\end{tabular}




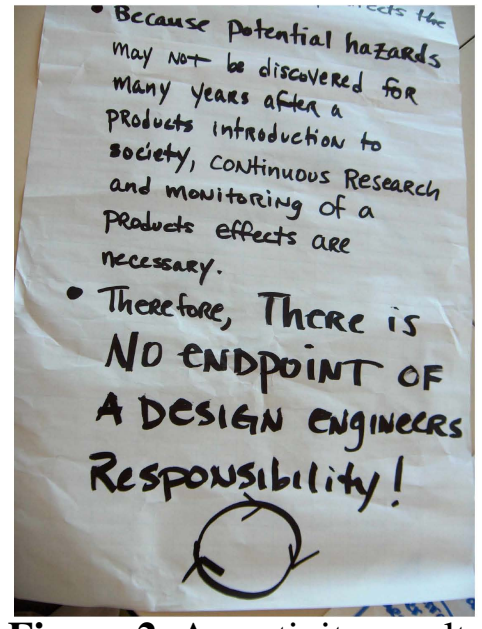

Figure 2. An activity result.

Each group summarized their decision and its rationale on a large piece of paper and posted the paper at the end of the class session. Figure 2 shows one team's answer. Their answers, like this one, indicate that the exercises are enabling them to see their role as an engineer as one of responsibility beyond the narrow scope of technical performance of a product.

Each activity requires that the team come up with a specific solution. In the process of deciding on the solution, individuals within the team must listen to the ideas of others and articulate their own ideas. We observed students actively engaged as they debated ideas with one another.

In short, we have witnessed: a) students taking more responsibility for their own learning; b) a high level of involvement by each student in the group activities; c) a high level of inquiry during minilectures; d) a high level of student enthusiasm toward the class, with students going out of their way to comment positively on the course design; and e) an increased level of confidence in students' intellectual abilities. Some of these observations are supported by the mid-point survey responses, while others come from the instructors' comparison of the course to other courses they have taught using traditional teaching formats. Because we have not completed this course at the time of the writing, the complete assessment of the course effectiveness will be published elsewhere.

\section{SUMMARY}

The interdisciplinary teaching challenge of nanotechnology was overcome in our sophomorelevel course, Nanotechnology, Biology, Ethics and Society, through utilizing a modified teambased learning structure. A librarian assisted students in developing skills around finding and professors were present throughout, but the course structure shifted responsibility to the students for their own learning and the application of their own learning. The result was high-energy classrooms where students were actively engaged in problem solving, critical thinking and debating ideas.

\section{ACKNOWLEDGEMENTS}

This work was supported in part by a grant from the National Science Foundation, Grant EEC\#0530760.

\section{REFERENCES}

${ }^{1}$ Michaelsen, L.K., A. Bauman Knight, L. D. Fink, eds., Team-Based Learning: A

Transformative Use of Small Groups in College Teaching (Sterling, VA: Stylus Publishing, LLC, 2004).

${ }^{2}$ Drexler, K., "Machine-Phase Nanotechnology," Scientific American (September 2001): 74-75.

${ }^{3}$ Schwartz, P.V., D.J. Lavrich, and G. Scoles, "Overlayers of Long Chain Organic Molecules Physisorbed on the Surface of Self-Assembled Monolayers of Alkylthiols on Au(111)"

Langmuir 19 (2003): 4969. 
${ }^{4}$ Schwartz, P.V., "Molecular Transport from an AFM tip: a Comparative Study of Dip-Pen Nanolithography," Langmuir 18 ( 2002): 4041.

${ }^{5}$ Springer, L., M.E. Stanne, and S.S. Donovan, "Effects of Small-Group Learning on Undergraduates in Science, Mathematics, Engineering, and Technology: A Meta-Analysis," Review of Educational Research 69 (1999): 1-21.

${ }^{6}$ Bolbeck, C.L., S.E. Campbell, and S.A. Bjorklund, "Grouping in the Dark," J. Higher Education 71 (2000): 1-16.

${ }^{7}$ Bloom, B.S., M.D. Englehart, E.J. Furst, W.H. Hill, and D.R. Krathwohl, Taxonomy of Educational Objectives: Handbook 1: Cognitive Domain. New York: Longman, 1956.

${ }^{8}$ Hutchison, M.A., D.K. Follman, M. Sumpter, G.M. Bodner, "Factors Influencing the SelfEfficacy Beliefs of First-Year Engineering Students," J. Engineering Educ. (\% (2006): 39-47.

${ }^{9}$ Bandura, Albert, Social Foundations of Thought and Action: A Social Cognitive Theory (New Jersey: Prentice Hall, 1986).

${ }^{10}$ Park, Robert L., "Voodoo Science: The Seven Warning Signs of Bogus Science," Chronicle of Higher Ed. 49(21) B20 (Jan 31, 2003).

${ }^{11}$ Merkle, R., "Self Replicating Systems and Molecular Manufacturing," www.zyvex.com/nanotech/selfRepJBIS.html (last accessed on May 1, 2006).

${ }^{12}$ Stix, G., "Little Big Science", Scientific American (September 2001): 32-37.

${ }^{13}$ Drexler, K., "Machine-Phase Nanotechnology," Scientific American (September 2001): $74-$ 75.

${ }^{14}$ Smalley, R., “Of Chemistry, Love and Nanobots," Scientific American (September 2001): 7677.

15 Steingraber, S., "The Pirates of Illiopolis," Orion vol 24, \#3 (May/June 2005): 16-27.

${ }^{16}$ Raven, P., "Science, Sustainability, and the Human Prospect," Science 297 (August 9, 2002): 954-958.

${ }^{17}$ Brongersma, M., "Nanoshells: Gifts in a gold wrapper," Nature Materials 2 (May 2003): 269-297.

${ }^{18}$ Loo, C., A. Lowery, N. Halas, J. West, and R. Drezek, "Immunotargeted Nanoshells for Integrated Cancer Imaging and Therapy," Nano Letters 5,4 (2005): 709-711.

${ }^{19}$ Service, R., "Nanotechnology Takes Aim at Cancer," Science 310 (November 18, 2005): 1132-1134.

${ }^{20}$ Chan, C., F. Berthiaume, B. Nath, A. Tilles, M. Toner, and M. Yarmush, "Hepatic Tissue Engineering for Adjunct and Temporary Liver Support: Critical Technologies," Liver Transplantation 10,11 (November 2004): 1331-1342.

${ }^{21}$ Ma, P., "Scaffolds for tissue fabrication," Materials Today (May 2004): 30-40.

${ }^{22}$ Kim, J-H, B-G. Kim, J-B. Yoon, E. Yoon, C-H. Han, "A new monolithic microbiosensor for whole blood analysis," Sensors and Actuators A, 95 (2002): 108-113. 